\title{
Role of Direct Cost in Unit Cost Based on Activity-Based Costing in the Inpatient Room of the MS General Hospital
}

\author{
Nuryadi $^{1^{*}}$, Widodo J. Pudjirahardjo ${ }^{2}$ \\ ${ }^{I}$ Doctoral Program, Public Health Faculty, Universitas Airlangga, Surabaya, Indonesia \\ ${ }^{2}$ Public Health Faculty, Universitas Airlangga, Surabaya, Indonesia \\ *Corresponding author. Email: nuryadi.169@gmail.com
}

\begin{abstract}
Unit cost was real cost at hospital care. Unit cost was component of rational services tariff. The problem was nothing of standarized proportion of direct cost and indirect cost on unit cost in the inpatient room. The purpose of this study was to compare direct cost and indirect cost in unit cost based on activity based costing in the inpatient room. Type of this research was survei using cross sectional approach. The location of this study was "MS" general hospital at year 2017. The analysis units of this study was inpatient rooms. Data analysis using descriptive. The results showed that direct cost higher than indirect cost in unit cost based on activity based costing. Overall, proportion of direct cost and indirect cost was 87,42\% and 12,58\%. Role Proportion of direct cost and indirect cost in Flamboyan Room was 94,36 and 5,64. Proportion of direct cost and indirect cost in Bougenville Room was 93,89 and 6,11. It's mean that direct cost had role largest in unit cost. Proportion of direct cost and indirect cost in Mawar Room was 89,75 and 10,25. Proportion of direct cost and indirect cost in Dahlia Room was 92,08 and 7,92. Proportion of direct cost and indirect cost in Kemuning Atas Room was 90,69 and 9,31. Proportion of direct cost and indirect cost in Kemuning Bawah Room was 78,34 and 21,66. Proportion of direct cost and indirect cost in Wijayakusuma Room was 76,84 and 23,16. Proportion of direct cost and indirect cost in Melati Room was 82,51 and 17,49. Proportion of direct cost and indirect cost in maternity Room was 88,31 and 11,69. The conclusion were direct cost higher than indirect cost on unit cost. Proportion direct cost and indirect cost been used to compare real cost and INA CBGs tariff.
\end{abstract}

Keywords: direct cost, indirect cost, unit cost, activity based costing

\section{INTRODUCTION}

The program of National Health Insurance (NHI) began to be implemented in Indonesia in 2014 and brought significant changes both in the service and financing systems, especially in hospitals. Problems faced in the NHI era were problems related to the quality of health services. Hospitals and other health service providers were required to provide excellence and comprehensive health services to public. In addition, hospitals were also required to improve the efficiency of health services in the NHI era (12). Increasing the number of NHI members increases the level of access to health facilities by public, which was marked by an increase in the visit of several diseases.
This condition had resulted in increased costs of providing health services (7). On the one hand, a significant increase of patient visits makes the workload of medical workers become heavier which impacts on the quality of their services (2). Changes in the payment mechanism in the NHI era caused the cost of health services provided by the hospital to follow the standards tariff set by the INA-CBGs. However, Ananta (2) said that the application of INA-CBS tariff according to several hospital management and health provider had not been able to cover the actual cost of health services provided (actual cost). Research conducted by Edya (9) shows that the cost recovery rate for inpatients who BPJS participants was $83.2 \%$, which means that the income of inpatients of Social Security Management Agency (SSMA)-Health members has not fully covered the operational costs of these patients, even though according to Azwar (5), availability of funds and facilities became an important factor influencing the quality of health services. The fact of its implementation showed that there were still 
some cost components that were considered to be too low compared to the claims paid by SSMA-Health to the Hospitals (8). The health financing system using the payment model using INA-CBGs tariff which was paid prospectively could be a threat to the hospital, especially if the INA-CBGs tariffs that were determined cannot cover the overall costs incurred by the hospital (7). Thus, the low claim rates by SSMA-Health to the hospitals potentially reduce the quality of hospital health services.

Hospital's tariff was the fees received by the hospital for services from both service and non-service activities provided to public. Hospital tariff is calculated based on the unit cost which is the result of calculating the total cost of each activity incurred by the hospital. Hospital tariff was calculated based on the components of facilities and services cost. The facility cost component consists of costs for the use of accommodation, non-medical materials, drugs, medical material and equipment devices that were used directly in health services and other supporting services. The service cost component consists of costs for services provided to patients by medical service providers, medical support services and or other services (14). On the other hand, the INA-CBG tariff was a tariff system based on the classification of the codification system were the output of services based on revised ICD-10 in 2010 for the diagnosis and revised ICD-9-CM in 2010 for interventions or procedures. The grouping was carried out using information technology systems in the form of INA-CBG applications which produced a total of 1,075 case groups consisting of 786 inpatient cases and 289 outpatient cases (15). The INA-CBG tariff was a tariff package consisting of all parts of hospital resources used in providing services to patients both medically and non-medically. The calculation of INA-CBG tariff was following hospital costing data and coding data. Costing data was data of costs that were spent by hospitals both operationally and investment, which were obtained from selected hospitals that represent the whole hospital. The coding data was obtained from NHI claim data. The INA-CBG tariff grouping was adjusted after looking at the amount of Hospital Base Rate (HBR) obtained from the calculation of the total cost of some hospitals. If there was more than one hospital in one group, the Mean Base Rate was used (15).

The difference between the hospital tariffs and the INA CBG tariff become a trigger for hospitals, especially in the NHI era, to standardize their tariff so that a difference does not cause the hospital to suffer losses. As one of the important input bases for standardizing tariffs, unit cost give an important role in obtaining information on budget planning, cost control, pricing, setting subsidies and assisting in decision making. The calculation process has the aim that the efficiency and performance of each installation, outpatient or component in the service process at health service provider institutions can be monitored properly (18). This is done so that the balance between hospital income and production costs can be planned as well as possible so that health care activities for patients can be carried out optimally, appropriately and affordably for the community (19). Using of unit cost as an indicator of the effectiveness and efficiency of health services according to Adhikari (1) is indeed widely used in developing countries, including Indonesia.

According to Hansen and Mowen (10), unit cost was the total cost associated with a unit produced divided by the number of units produced. According to Supriyono (21), unit cost was all cost incurred in carrying out production activities or producing services divided by the number of activities or services produced. One of the most effective unit cost calculation methods used to calculate unit cost was the Activity-Based Costing (ABC) method. Activity-based costing was a method that applies the concept of activity accounting to produce more accurate product cost calculations. In a managerial perspective, ABC systems offer more than just accurate product cost information but also provide information about costs and performance of activities and resources, and also can track costs accurately to cost objects (17). The steps in designing activity-based costing according to Mulyadi (17), were carried out in two stages: the first was activity-based process costing, and the second stage was activity-based object costing. Activitybased process costing was the stage where costs were classified into two major groups, including direct costs and indirect costs. Direct cost was costs that arise due to the use of resources that were entirely caused by the giving of health interventions (16). According to Jayanti (13), direct cost was a cost incurred due to something being financed.

According to Bastian (6), direct costs represent costs incurred or used directly in production activities in a production unit. Types of direct costs such as staff costs and equipment costs used in production activities. The characteristic of direct costs was that the allocation of costs or inputs that have been determined can be compared with the output or the product produced. Indirect cost was cost incurred and come from various activities in addition to production activities that were interrelated (6). According to Jayanti (13), indirect cost was a cost that occurs not only because of something being financed. Bastian (6) defines indirect cost as a cost incurred and derived from various activities other than interrelated production activities. This cost was not directly affected by the activities or programs in the organization. Indirect costs are usually used periodically, generally monthly in order to coordinating the implementation of generally organizational authority.

The next in this stage, the direct costs recording of products or services were done in two stages, namely costs recording per activity and costs recording per product or service. The recording of indirect costs of products or services, these costs were divided into two groups, namely costs that can be imposed directly to activities through direct tracing were recorded separately, while costs that cannot be imposed 
directly and use the resource driver in loading were recorded and added separately in the responsibility account system. The second stage is activity-based object costing. Activity-based object costing consist of 1) determination of the activity cost pool, it's carried out to determine the group of activities of each product or service, 2) the imposition of costs between activities using certain activities, therefore it needs to be imposed to the activities that consume them, and 3 ) imposition of result-producing costs to the cost object (17) . Therefore, direct cost information was key and important and also very necessary in calculating unit costs based on the ABC method.

Previous study that has been conducted by Destanul Aulia, Sri Fajar Ayu, Nefonafratilova (4) about a comparative analysis of direct costs and indirect cost for stroke patients in a hospital. That study discusses in different contexts, the direct cost was a cost borne by the SSMA-Health, while the indirect cost was a cost borne by patients. In addition, the discussion was only on one disease, namely stroke. Thus, an understanding of the direct costs and indirect costs in health services in hospitals was very important to know and analyze with the aim of providing an understanding of the services and clinical procedures provided in each service process (23). In addition, information related to direct costs and indirect costs can be a tool for monitoring and controlling of costs and can determine the production sites that give profit or even cause losses. The availability of data related to direct and indirect cost, it can compare the cost of health services with competitors based on differences in the quality of services, costs, ways of providing, and determining tariff (23). Based on the above discussion, a study of the proportion of direct and indirect cost in unit cost using the $\mathrm{ABC}$ method was carried out in the inpatient unit of the "MS" general hospital. The problem was nothing of standarized proportion of direct cost and indirect cost on unit cost in the inpatient room. The purpose of this study was to compare direct cost and indirect cost in unit cost based on activity based costing in the inpatient room.

\section{METHOD}

Type of this research was a survey using a cross-sectional approach. The location of this study was the general hospital "MS" in 2017. The analysis units of this study were inpatient rooms consisting of Flamboyan rooms, Bougainville rooms, Mawar rooms, Dahlia rooms, Kemuning Atas room, Kemuning Bawah room, Wijaya Kusuma room, Melati room and maternity room. The research variable consists of direct cost and indirect cost. Direct cost consists of consumable medical costs, medical or paramedical personnel costs, and medical equipment cost. Indirect costs consist of indirect costs at the production unit and indirect cost at the facility activity (non-production unit). Indirect cost on the production unit consists of building depreciation cost, non-medical equipment depreciation cost, non-medical consumable cost, general costs (electricity, water, telephone and internet), other operational costs, and maintenance cost. The indirect cost of facility activity consists of building depreciation costs, vehicle depreciation cost, non-medical equipment depreciation cost, non-medical consumable cost, general costs (electricity, water, telephone and internet), other operational costs, and maintenance costs. Secondary data were collected using the form. Data analysis using descriptive.

\section{RESULTS AND DISCUSSION}

The results of research conducted at the "MS" general hospital in 2017 consisted of nine stages. First, identify the product (type) of service in each production unit (in this case was inpatient room) and the number of services (patients) per type of service. At this stage, it that described in this paper was only the overall type of service from the production unit. Second, identification of activities per type of service and the time (described in appendix). Third, calculating direct cost per type of service in each production unit, including consumable medical materials cost, medical and paramedics personnel cost, medical equipment, cost, then calculated the total of direct cost. At this stage, it that described in this paper was only the average of the total direct cost of all types of services per production unit. Fourth, calculating the indirect cost in the production unit, including investment cost (building depreciation, and depreciation of non-medical equipment); operational cost [non-medical consumables, general costs (electricity, water, telephone and internet), other operational costs]; and maintenance cost, then calculated the total indirect cost. At this stage, it that described in this paper was only the total indirect cost per production unit. Fifth, identify facility activity in non-production units and cost drivers (described in the appendix). Sixth, calculating the indirect cost in facility activity, including investment cost (building depreciation, vehicle depreciation, and depreciation of nonmedical equipment); operational cost [non-medical consumables, general costs (electricity, water, telephone and internet), other operational costs]; and maintenance cost, then the total indirect cost were calculated. At this stage, it that described in this paper was only the total indirect costs for each facility activity. The seventh, imposing indirect cost on the facility activity to the production unit. At this stage, it that described in this paper was only the amount of total indirect costs in facility activity which was imposed to the inpatient room as a production unit. Eighth, the imposition of indirect costs in each production unit and facility activity to each type of service per production unit. At this stage, it that described in this paper was only the average of total indirect costs of the whole type of service per production unit. Ninth, it recapitulate direct costs and indirect costs and determine the proportion in percentage. The results of identification and calculation that can be described in this paper are as follows (it only that described in this paper): 


\section{Products (Types) Services in Each Production Unit}

Table 1. Products (Types) Of Services in Each Production Unit

\begin{tabular}{|c|c|c|c|c|c|c|c|c|c|c|}
\hline No. & $\begin{array}{l}\text { Types of Services } \\
\text { Products }\end{array}$ & $\begin{array}{l}\text { Flam } \\
\text { boyan } \\
\text { Room }\end{array}$ & $\begin{array}{l}\text { Bouge } \\
\text { nville } \\
\text { Room }\end{array}$ & $\begin{array}{l}\text { Mawa } \\
\quad \mathbf{r} \\
\text { Room }\end{array}$ & $\begin{array}{c}\text { Dahli } \\
\text { a } \\
\text { Room }\end{array}$ & 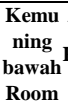 & $\begin{array}{c}\text { Wijaya } \\
\text { Kusuma } \\
\text { Room }\end{array}$ & $\begin{array}{l}\text { Kemu } \\
\text { ning } 1 \\
\text { Atas } \\
\text { Room }\end{array}$ & $\begin{array}{l}\text { Melati } \\
\text { Room }\end{array}$ & $\begin{array}{l}\text { Mater } \\
\text { nity } \\
\text { Room }\end{array}$ \\
\hline 1. & Injection & $\sqrt{ }$ & & $\sqrt{ }$ & $\sqrt{ }$ & $\sqrt{ }$ & $\sqrt{ }$ & $\sqrt{ }$ & $\sqrt{ }$ & $\sqrt{ }$ \\
\hline 2. & Nebulizer & $\sqrt{ }$ & $\sqrt{ }$ & $\checkmark$ & $\sqrt{ }$ & $\sqrt{ }$ & $\checkmark$ & $\sqrt{ }$ & $\sqrt{ }$ & $\checkmark$ \\
\hline 3. & Infusion & $\checkmark$ & $\sqrt{ }$ & $\checkmark$ & $\sqrt{ }$ & $\sqrt{ }$ & $\sqrt{ }$ & $\sqrt{ }$ & $\sqrt{ }$ & $\sqrt{ }$ \\
\hline 4. & Catheter Installation & $\sqrt{ }$ & $\sqrt{ }$ & $\checkmark$ & $\sqrt{ }$ & $\sqrt{ }$ & $\sqrt{ }$ & $\sqrt{ }$ & $\sqrt{ }$ & $\sqrt{ }$ \\
\hline 5. & $\begin{array}{l}\text { Oxygen Installation with } \\
\text { Nasal Canules }\end{array}$ & $\checkmark$ & $v$ & $\checkmark$ & 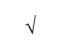 & $\checkmark$ & $\checkmark$ & $\checkmark$ & $\sqrt{ }$ & $\sqrt{ }$ \\
\hline 6. & Blood Sampling & $\sqrt{ }$ & $\sqrt{ }$ & $\sqrt{ }$ & $\sqrt{ }$ & $\sqrt{ }$ & $\sqrt{ }$ & $\sqrt{ }$ & $\sqrt{ }$ & $\sqrt{ }$ \\
\hline 7. & Blood Transfusion & $\sqrt{ }$ & $\sqrt{ }$ & $\checkmark$ & $\checkmark$ & $\sqrt{ }$ & $\checkmark$ & $\checkmark$ & $\checkmark$ & $\checkmark$ \\
\hline 8. & $\begin{array}{l}\text { Basic of Nursing / } \\
\text { Midwifery Per Day }\end{array}$ & $\checkmark$ & $\sqrt{ }$ & $\checkmark$ & $\checkmark$ & $\checkmark$ & $\sqrt{ }$ & $\checkmark$ & $\sqrt{ }$ & $\sqrt{ }$ \\
\hline 9. & $\begin{array}{l}\text { Class II Room } \\
\text { Accommodations }\end{array}$ & $\checkmark$ & $\sqrt{ }$ & $\checkmark$ & & & & & $\sqrt{ }$ & $\checkmark$ \\
\hline 10. & $\begin{array}{l}\text { Class III Room } \\
\text { Accommodations }\end{array}$ & $\checkmark$ & $\sqrt{ }$ & $\sqrt{ }$ & & & & & $\sqrt{ }$ & $\sqrt{ }$ \\
\hline $11 .^{\mathrm{I}}$ & $\begin{array}{l}\text { Isolation Room } \\
\text { Accommodation }\end{array}$ & $\sqrt{ }$ & & $\sqrt{ }$ & & $\sqrt{ }$ & & & & \\
\hline 12. & Class I Accommodation & & & & & & & $\sqrt{ }$ & $\sqrt{ }$ & $\sqrt{ }$ \\
\hline 13. & $\begin{array}{l}\text { VVIP Class Room } \\
\text { Accommodation }\end{array}$ & & & & & & & $\checkmark$ & & $\checkmark$ \\
\hline 14. & $\begin{array}{l}\text { Visite Doctor Class I, Main, } \\
\text { VIP, VVIP }\end{array}$ & & & & & $\sqrt{ }$ & $\sqrt{ }$ & $\sqrt{ }$ & $\sqrt{ }$ & $\sqrt{ }$ \\
\hline 15. & Visite Doctor Class II, III & $\sqrt{ }$ & $\sqrt{ }$ & $\sqrt{ }$ & & & & & $\sqrt{ }$ & $\sqrt{ }$ \\
\hline 16. & $\begin{array}{l}\text { Doctor Consultation } \\
\text { (Including On Call) }\end{array}$ & $\sqrt{ }$ & $\sqrt{ }$ & $\sqrt{ }$ & $\sqrt{ }$ & $\checkmark$ & $\sqrt{ }$ & $\sqrt{ }$ & $\sqrt{ }$ & $\sqrt{ }$ \\
\hline
\end{tabular}

Table 1. Shows that overall there were 150 types of services in the inpatient rooms of the "MS" general hospital which were calculated their unit cost. Each inpatient room was an average of about 58 different service products and it's adjusted to the capacity and components of the inpatient room. Some intervention in all inpatient rooms include nebulizer, infusion, urin catheter, oxygen setting up with nasal canules, blood sampling, blood transfusion, basic daily care, room accommodation, doctor's visite and doctor's consultation.

This list of types of service can provide an illustration for other hospitals when calculating the unit cost and tariff per procedure. In this NHI era, unit cost and tariff per procedure were very beneficial for hospitals as part of tools in cost control. Hospitals can find out how much money is spent per day by patients of SSMA-Health's members or patients of non SSMA-Health's (general) by monitoring the billing system. In addition, unit cost and tariff per procedure when combined with clinical pathways can produce a cost of treatment per diagnosis and a tariff per diagnosis. This is in line with research conducted by Noer Triyanto Rusli (20) on cost analysis and determinants of hemodialysis services inefficiency analysis in patients with renal failure in RK Charitas Palembang Hospital. That study suggests that with the enactment of NHI in hospitals, it will change the payment system from a retrospective payment (fee for service) to a prospective payment system (INA-CBG's).

In addition, Tejosukmono (22) also mentioned that hospitals can compare unit costs with INA-CBG tariff, so hospitals can make cost efficiency adjustments without having to imposed these service costs to patients. As one of the health care facilities, RK Charitas Hospital has the role to provide quality services while still give attention to the cost-effective services provided. Cost analysis using the activity-based costing (ABC) approach with the bottom-up method can determine the cost allocation by identifying the cost per type of hemodialysis service. The stages of identification of activities per type of service and time are described in the appendix because of the presentation priority of research results, and because too many will be described.

\section{Total Direct Costs per Type of Service in Each Production Unit}

The total direct costs per type of service in each production unit are described as a whole per unit of production in the inpatient of local general hospital "MS" which consists of a Flamboyant Room, Bougenville Room, Mawar Room, Dahlia Room, Kemuning Atas Room, Kemuning Bawah Room, Wijaya Kusuma Room, Melati Room and Maternity Room. The total direct costs in this study consisted of the cost of consumable medical materials, medical personnel and paramedical costs, and the cost of medical devices. The details per component of the direct costs per type of service per unit of production are described in the appendix because too much will be described.

Table 2. Average of Total Direct Costs of Overall Service Types per Production Unit

\begin{tabular}{|c|c|c|c|c|c|}
\hline & $\begin{array}{c}\text { Production } \\
\text { Unit }\end{array}$ & $\begin{array}{c}\text { Average } \\
\text { of Total } \\
\text { Direct } \\
\text { Costs } \\
\text { (IDR) }\end{array}$ & No. & $\begin{array}{c}\text { Production } \\
\text { Unit }\end{array}$ & $\begin{array}{c}\text { Average } \\
\text { of Total } \\
\text { Direct } \\
\text { Costs } \\
\text { (IDR) }\end{array}$ \\
\hline 1 & $\begin{array}{l}\text { Flamboyan } \\
\text { Room }\end{array}$ & 111.566 & 6. & $\begin{array}{l}\text { Wijaya } \\
\text { Kusuma } \\
\text { Room }\end{array}$ & 91.340 \\
\hline 2 & $\begin{array}{l}\text { Bougenville } \\
\text { Room }\end{array}$ & 123.837 & 7. & $\begin{array}{l}\text { Kemuning } \\
\text { Atas Room }\end{array}$ & 117.566 \\
\hline 3 & $\begin{array}{l}\text { Mawar } \\
\text { Room }\end{array}$ & 72.624 & 8. & $\begin{array}{l}\text { Melati } \\
\text { Room }\end{array}$ & 63.479 \\
\hline 4 & $\begin{array}{l}\text { Dahlia } \\
\text { Room }\end{array}$ & 143.434 & 9. & $\begin{array}{l}\text { Maternity } \\
\text { Room }\end{array}$ & 97.588 \\
\hline 5 & $\begin{array}{l}\text { Kemuning } \\
\text { Bawah } \\
\text { Room }\end{array}$ & 125.747 & & & \\
\hline
\end{tabular}

Costs was in the Dahlia Room with a total direct cost of IDR 143.434. It's because the Dahlia room has the highest number of service products compared to other inpatient rooms, namely 48 service products. While the lowest average of total direct costs was in the Melati Room with a total direct cost of IDR 63.479 with 34 service products. The direct cost component consists of the consumable medical materials cost, medical personnel and paramedical costs, and medical equipment cost per type of procedure. Direct costs in this study differ from the definition of direct cost used in the research of Noer Triyanto Rusli (20), and Destanul Aulia, Sri Fajar Ayu, Nur Hidayah Nasution (3) that the direct costs consist of consumable medical materials, investment costs, operational costs and maintenance costs in the production unit. Likewise, according to Destanul Aulia, Sri Fajar A, and Nefonafratilova (4) in the context of treatment costs that the 
services, laundry services, equipment maintenance services, building maintenance services, electricity and sanitation services, cleaning and garden services, security services, and waste management services. The description of investment costs (buildings depreciation, vehicles depreciation, and non-medical equipment depreciation), operational costs [non-medical consumables, general costs (electricity, water, telephone and internet), other operational costs]; and maintenance costs for each facility activity were described in the appendix because too much will be described. (Table 4).

Table 4. Total Indirect Costs For Each Activity Activity

\begin{tabular}{|c|c|c|c|c|c|}
\hline No. & $\begin{array}{l}\text { Facility } \\
\text { Activity }\end{array}$ & $\begin{array}{c}\text { Total of } \\
\text { Indirect Cost in } \\
\text { FA (IDR) }\end{array}$ & No. & $\begin{array}{l}\text { Facility } \\
\text { Activity }\end{array}$ & $\begin{array}{c}\text { Total of } \\
\text { Indirect Cost in } \\
\text { FA (IDR) }\end{array}$ \\
\hline 1. & $\begin{array}{r}\text { Management } \\
\text { Services (Offices) }\end{array}$ & 7.397.647.784 & 8. & $\begin{array}{l}\text { Laundry } \\
\text { Service }\end{array}$ & 329.890 .049 \\
\hline 2. & $\begin{array}{l}\text { Medical } \\
\text { Record }\end{array}$ & 959.215 .042 & 9. & $\begin{array}{l}\quad \text { Equipment } \\
\text { Maintenance } \\
\text { Services }\end{array}$ & 736.696 .974 \\
\hline 3. & HMIS Services & 55.964 .337 & 10. & $\begin{array}{l}\text { The } \\
\text { Building, } \\
\text { Electricity, and } \\
\text { Sanitation } \\
\text { Maintenance } \\
\text { Services }\end{array}$ & 742.494 .749 \\
\hline 4. & $\begin{array}{l}\text { Pharmaceutical } \\
\text { services }\end{array}$ & 1.139.116.492 & 11. & $\begin{array}{l}\text { Cleaning } \\
\text { and Garden } \\
\text { Service }\end{array}$ & 179.423 .724 \\
\hline 5. & $\begin{array}{l}\text { Nutrition } \\
\text { services }\end{array}$ & 310.972 .832 & 12. & $\begin{array}{l}\text { Security } \\
\text { Services }\end{array}$ & 614.853 .209 \\
\hline 6. & $\begin{array}{l}\quad \text { Training and } \\
\text { Development } \\
\text { Research Services }\end{array}$ & 424.669 .587 & 13. & $\begin{array}{l}\text { Waste } \\
\text { Management } \\
\text { Services }\end{array}$ & 952.648 .577 \\
\hline 7. & CSSD Services & 1.473 .399 .199 & & & \\
\hline
\end{tabular}

Table 4 shows that the total indirect costs for each facility activity. There were 13 activity support units that support health services provided in the inpatient room. Based on the table above, the highest indirect costs was in management service activity support units (office) which IDR 7.397.647.784.

Indirect costs in facility activity in this study differ from the definition of indirect costs used in Noer Triyanto Rusli's (20) study that indirect costs were supporting costs in the form of building investment, operational costs and maintenance of supporting units including management. Likewise, according to Destanul Aulia, Sri Fajar Ayu, Nefonafratilova (4) that indirect costs were costs of outside the service borne by their own patients and families, including transportation costs, costs of lost productivity, and companion costs (accompanying patient by family members).

\section{Imposing Indirect Costs in Facility Activity to the Production Unit}

Imposing indirect costs on facility activities (nonproduction supporting units) of "MS" general hospital to production units consisting of Flamboyant Room, Bougenville Room, Mawar Room, Dahlia Room, Kemuning Atas Room, Kemuning Bawah Room, Wijaya Kusuma Room, Melati Room and Maternity Room through 
facility activity to each type of service per production unit was described in the appendix because too much to be described.

Table 6 Average of Total Indirect Costs of Whole Types of indirect costs per facility activity divided by the number of cost drivers per facility activity. The amount of indirect costs imposed is obtained from the rate per cost driver for each facility activity to be imposed multiplied by the number of cost drivers per production unit that will get the impose. The calculation of the rate per cost driver for each facility activity and the amount of indirect costs for the facility activity imposed was described in the appendix because too much will be described.

Table 5. Total of Indirect Costs in Facility Activity That Imposed To the Production Unit

\begin{tabular}{|c|c|c|c|c|c|}
\hline No. & $\begin{array}{l}\text { Production } \\
\text { Unit }\end{array}$ & $\begin{array}{c}\text { Total of } \\
\text { Indirect } \\
\text { Costs in } \\
\text { Facility } \\
\text { Activity } \\
\text { that } \\
\text { Imposed to } \\
\text { The } \\
\text { Production } \\
\text { Unit } \\
\text { (IDR) }\end{array}$ & No. & $\begin{array}{l}\text { Production } \\
\text { Unit }\end{array}$ & $\begin{array}{c}\text { Total of } \\
\text { Indirect } \\
\text { Costs in } \\
\text { Facility } \\
\text { Activity } \\
\text { that } \\
\text { Imposed to } \\
\text { The } \\
\text { Production } \\
\text { Unit } \\
\text { (IDR) }\end{array}$ \\
\hline 1. & $\begin{array}{l}\text { Flamboyan } \\
\text { Room }\end{array}$ & 928.617 .422 & 6. & $\begin{array}{c}\text { Wijaya } \\
\text { Kusuma Room }\end{array}$ & 668.927 .945 \\
\hline 2. & $\begin{array}{l}\text { Bougenville } \\
\text { Room }\end{array}$ & 825.112 .143 & 7. & $\begin{array}{l}\text { Kemuning } \\
\text { Atas Room }\end{array}$ & 611.931 .559 \\
\hline 3. & $\begin{array}{l}\text { Mawar } \\
\text { Room }\end{array}$ & 415.972 .766 & 8. & $\begin{array}{l}\text { Melati } \\
\text { Room }\end{array}$ & 424.845 .023 \\
\hline 4. & $\begin{array}{l}\text { Dahlia } \\
\text { Room }\end{array}$ & 348.544 .628 & 9. & $\begin{array}{l}\text { Maternity } \\
\text { Room }\end{array}$ & 189.426 .694 \\
\hline 5. & $\begin{array}{l}\text { Kemuning } \\
\text { Bawah Room }\end{array}$ & 569.505 .925 & & & \\
\hline
\end{tabular}

Table 5 shows that the total indirect costs in the activity support units imposed to all inpatient rooms, the highest total was in the Flamboyan Room at IDR 928.617.422. While the lowest total indirect costs in the activity support unit which is imposed to all inpatient rooms was in the Maternity Room at IDR 189.426.694.

Imposing indirect costs in each facility activity to the production unit in this study is different from the method of imposing in Noer Triyanto Rusli's (20) study that the loading uses an allocation basis of $23.24 \%$ and it is not explained how the loading process.

\section{Imposing Indirect Costs in Each Production Unit and Facility Activity to Each Type of Service per Production Unit}

The total indirect costs per type of service in each production unit are described as a whole per unit of production in the inpatient of "MS" general hospital which consists of Flamboyant Room, Bougenville Room, Mawar Room, Dahlia Room, Kemuning Atas Room, Kemuning Bawah Room, Wijaya Kusuma Room, Melati Room and Maternity Room. The calculation process on imposing indirect costs to the production unit to each type of service per production unit and the imposition of indirect costs on Services per Production Unit

\begin{tabular}{|c|c|c|c|c|c|}
\hline No. & $\begin{array}{l}\text { Production } \\
\text { Unit }\end{array}$ & $\begin{array}{c}\text { Average } \\
\text { of Total } \\
\text { Indirect } \\
\text { Costs of } \\
\text { Whole } \\
\text { Types of } \\
\text { Services per } \\
\text { Production } \\
\text { Unit (IDR) }\end{array}$ & No. & $\begin{array}{l}\text { Production } \\
\text { Unit }\end{array}$ & $\begin{array}{c}\text { Average } \\
\text { of Total } \\
\text { Indirect } \\
\text { Costs of } \\
\text { Whole } \\
\text { Types of } \\
\text { Services per } \\
\text { Production } \\
\text { Unit (IDR) }\end{array}$ \\
\hline 1. & $\begin{array}{l}\text { Flamboyan } \\
\text { Room }\end{array}$ & 6.827 & 6. & $\begin{array}{c}\text { Wijaya } \\
\text { Kusuma Room }\end{array}$ & 20.755 \\
\hline 2. & $\begin{array}{l}\text { Bougenville } \\
\text { Room }\end{array}$ & 6.003 & 7. & $\begin{array}{l}\text { Kemuning } \\
\text { Atas Room }\end{array}$ & 8.043 \\
\hline 3. & $\begin{array}{l}\text { Mawar } \\
\text { Room }\end{array}$ & 9.504 & 8. & $\begin{aligned} & \text { Melati } \\
& \text { Room }\end{aligned}$ & 13.836 \\
\hline 4. & $\begin{array}{l}\text { Dahlia } \\
\text { Room }\end{array}$ & 10.938 & 9. & $\begin{array}{l}\text { Maternity } \\
\text { Room }\end{array}$ & 9.331 \\
\hline 5. & $\begin{array}{l}\text { Kemuning } \\
\text { Bawah Room }\end{array}$ & 21.559 & & & \\
\hline
\end{tabular}

Imposing indirect costs in each unit of production and facility activity to each type of service per production unit in this study was different from the method of imposing in the Noer Triyanto Rusli research (20) that indirect costs were not imposed in each production unit because that indirect costs were categorized as direct costs, while there was also no imposing of indirect cost in activity facilities (supporting units) to each type of service per production unit because the costs that calculated was only service costs in one unit of production, for example, hemodialysis service costs.

The recapitulation of direct costs and indirect costs per type of service in each production unit was described as a whole per production unit in the inpatient of "MS" general hospital which consists of Flamboyant Room, Bougenville Room, Mawar Room, Dahlia Room, Kemuning Atas Room, Kemuning Bawah Room, Wijaya Kusuma Room, Melati Room and Maternity Room. The direct costs and indirect costs per type of service in each production unit, and the percentage were described in the appendix because too much will be described.

\section{Recapitulation of Direct Costs and Indirect Costs and Proportions in Percentages}


Table 7. Recapitulation of Direct Costs and Indirect Costs and Proportions in Percentages

\begin{tabular}{|c|c|c|c|c|c|}
\hline \multirow[t]{2}{*}{ No. } & \multirow[t]{2}{*}{$\begin{array}{l}\text { Production } \\
\text { Unit }\end{array}$} & \multicolumn{2}{|c|}{$\begin{array}{l}\text { Average of Total } \\
\text { Direct Costs of Whole } \\
\text { Types of Service Per } \\
\text { Production Unit }\end{array}$} & \multicolumn{2}{|c|}{$\begin{array}{c}\text { Average of Total } \\
\text { Indirect Costs of Whole } \\
\text { Types of Services per } \\
\text { Production Unit }\end{array}$} \\
\hline & & IDR & $\%$ & IDR & $\%$ \\
\hline 1. & $\begin{array}{l}\text { Flamboyan } \\
\text { Room }\end{array}$ & 111.566 & 94,36 & 6.827 & 5,64 \\
\hline 2. & $\begin{array}{l}\text { Bougenville } \\
\text { Room }\end{array}$ & 123.837 & 93,89 & 6.003 & 6,11 \\
\hline 3. & Mawar Room & 72.624 & 89,75 & 9.504 & 10,25 \\
\hline 4. & Dahlia Room & 143.434 & 92,08 & 10.938 & 7,92 \\
\hline 5. & $\begin{array}{l}\text { Kemuning } \\
\text { Bawah Room }\end{array}$ & 125.747 & 78,34 & 21.559 & 21,66 \\
\hline 6. & $\begin{array}{l}\text { Wijaya Kusuma } \\
\text { Room }\end{array}$ & 91.340 & 76,84 & 20.755 & 23,16 \\
\hline 7. & $\begin{array}{l}\text { Kemuning Atas } \\
\text { Room }\end{array}$ & 117.566 & 90,69 & 8.043 & 9,31 \\
\hline 8. & Melati Room & 63.479 & 82,51 & 13.836 & 17,49 \\
\hline \multirow[t]{2}{*}{9.} & Maternity Room & 97.588 & 88,31 & 9.331 & 11,69 \\
\hline & $\begin{array}{l}\text { Average in } \\
\text { Overall Inpatient } \\
\text { Rooms }\end{array}$ & 105.242 & 87,42 & 11.866 & 12,58 \\
\hline
\end{tabular}

Table 7 shows that the highest proportion of average of total direct costs was in the Flamboyan Room with a proportion of $94.36 \%$ or IDR 111.566. The lowest proportion of average of total direct costs was in the Wijaya Kusuma Room with a proportion of $76.84 \%$ or IDR 91.340 . But the proportion of average of total indirect costs in the Wijaya Kusuma Room with a proportion of $23.16 \%$ or IDR 20.755 was the highest proportion of average of total indirect costs. While the lowest proportion of average of total indirect costs was in the Flamboyan Room with a proportion of $5.64 \%$ or IDR 6.827 . Proportion of the average percentage of direct costs and indirect costs in the overall inpatient room was $87.42 \%$ or IDR 105.242 and $12,58 \%$ of Rp. 11.866. Research conducted by Noer Triyanto Rusli (20) showed that direct costs amounted to $76.76 \%$ and indirect costs amounted to $23.24 \%$. In this calculation, direct costs consist of consumable medical materials, investment costs, operational costs and maintenance costs in the production unit, while indirect costs consist of investment costs, operational costs and maintenance costs in non-production supporting units.

\section{CONCLUSION}

The conclusion, direct cost had role higest in unit cost calculation based on ABC. Direct cost were higher than indirect cost on unit cost. Overall, proportion of direct cost and indirect cost was $87,42 \%$ and $12,58 \%$. Proportion direct cost and indirect cost been used to compare real cost and INA CBGs tariff. This study recommends that: 1) the boundary equation between direct and indirect costs needs to be done, especially in calculating unit costs using the ABC method, 2) the determination of INA CBGs tariff must be above direct costs so that hospitals can cover the minimum operational costs incurred for direct services to patients, 3) hospitals should determine rational tariff, namely based on direct costs and non-direct costs (unit cost) so as not to sacrifice the community, especially patients and families.

\section{REFERENCES}

[1] Adhikari, S. R. 2015. A New Approach of Measuring Hospital Performance for Low- and Middle-income Countries. J Korean Med Sci, 30 (11):143-148.

[2] Ananta, I. 2016. Penerapan Pola Pembayaran InaCBGs dan Implementasi', in Seminar Nasional dan Call for Papers "Tantangan Pengembangan Ilmu Akuntansi, Inklusi Keuangan, dan Kontribusinya Terhadap Pembangunan Ekonomi Berkelanjutan: 275-290.

[3] Aulia, D, Ayu, S F dan Nasution, N H. 4, 2017, Analisis Upaya Rumah Sakit dalam Menutupi Kekurangan Biaya Klaim Indonesia Case Base Group (INA-CBGs) Yang Dihitung dengan Metode Activities Base Costing pada Rumah Sakit Swasta Kelas C di Kota Medan Tahun 2017. Jurnal Ekonomi Kesehatan Indonesia, Vol. 1, hal. 159. 166.

[4] Aulia, D, Ayu, S F dan Nefonafratilova. 2, 2017 , Analisis Perbandingan Biaya Langsung (Direct Cost) dan Biaya Tidak Langsung (Indirect Cost) pada Pasien Stroke di Rumah Sakit. Jurnal Ekonomi Kesehatan Indonesia. Vol. 2, hal. 82-88.

[5] Azwar, A. 1994. Program Menjaga Mutu Pelayanan Kesehatan: Aplikasi Prinsip Lingkaran Pemecahan Masalah. Jakarta: Pustaka Sinar Harapan Bastian, I. Akuntansi Kesehatan. Yogyakarta : PT Gelora Aksara Pratama, 2008.

[6] Bastian, I. Akuntansi Kesehatan. Yogyakarta : PT Gelora Aksara Pratama, 2008.

[7] BPJS Kesehatan. Peranan BPJS Kesehatan dalam Peningkatan Pelayanan Kesehatan. 2017.

[8] —. Info BPJS Kesehatan. Media Eksternal BPJS Kesehatan. 44, 2016.

[9] Edya, F. 201. Analisis Perbandingan Tarif INACBG's dengan Tarif Rumah Sakit dan Cost 
[22] Tejosukmono, A. 2017. Strategy Analysis of

Recovery Rate Pasien Rawat Inap Peserta Bpjs Kesehatan (Studi Kasus pada RSUD dr. Achmad Mochtar Bukittinggi). [thesis]. Universitas Andalas.

[10] Hansen, M. Management Accounting: Oklahoma State University. s.l. : South-Western College Publishing, 2003.

[11]Hastono, S.P.. Analisis Data pada Bidang Kesehatan. Jakarta : Rajawali Pers, 2016.

[12] Honda, A. et al. 2016. Strategy Purchasing in China, Indonesia and Philiphines.

[13] Jayanti, N. 2014. Penerapan Activity Based Costing Pada Tarif Jasa Rawat Inap Rumah Sakit (Studi Pada Rumah Sakit Wiyung Sejahtera Surabaya)', Jurnal Ilmu \& Riset Akuntansi, 3(9).

[14] Kementerian Kesehatan RI. Peraturan Menteri Kesehatan RI Nomor 85 Tahun 2015 tentang Pola Tarif Nasional Rumah Sakit. Jakarta : s.n., 2015.

[15] - Peraturan Menteri Kesehatan Republik Indonesia No. 76 Tahun 2016 tentang Pedoman Indonesian Case Base Groups (INA-CBGs) dalam Pelaksanaan Jaminan Kesehatan Nasional. 2016.

[16] Kirch, W. 2008. Encyclopedia of Public Health. Edited by B. Tucker. New York: Springer Science and Bussines Media.

[17] Mulyadi. Activity Based Cost System. Sistem Informasi Biaya Untuk Pemberdayaan Karyawan, Pengurangan Biaya, dan Penentuan Secara Akurat Kos Produk dan Jasa. Yogjakarta. s.l. : UPPSTIM YKPN, 2007.

[18] Peacock, S. and Johansen, D. 2001. Techniques for Measuring Efficiency in Health Services: Productivity Commission Staff Working Paper.

[19] Riewpaiboon, A., Rajbhandari, S. and Coyte, P. C. 2016. Effect of costing methods on unit cost of hospital medical services: A case of capital cost', Mahidol Univ J Pharm Sci, 43(2): 97-105.

[20] Rusli, N.T. 2016. Analisis Biaya dan Faktor-Faktor Penentu Inefisiensi Layanan Hemodialisis pada Pasien Gagal Ginjal Kronik Rumah Sakit Rk Charitas Palembang Tahun 2016. Jurnal Administrasi Rumah Sakit, 2017. 3 (3) : 158-168

[21] Supriyono, R A. Akuntansi Biaya. 2. Yogyakarta : BPFE Yogyakarta, 2011.
Muhammadiyah Gamping Hospital Facing National Health Insurance, in Proceeding International Seminar of Occupational Health and Medical Sciences (I-Socmed). Semarang: Faculty of Medicine, Muhammadiyah University of Semarang: 56-62.

[23] Trisnantoro, L. Memahami Penggunaan Ilmu Ekonomi dalam Manajemen Rumah Sakit. 4. Yogyakarta : Gajah Mada University Press, 2009. 